\title{
A Critical Review of Multinational Companies, Their Structures and Strategies and Their Link with International Human Resource Management
}

\author{
Fayaz Ali Shah ${ }^{1}$, Dr. Rosman Md Yusaff ${ }^{2}$, Altaf Hussain ${ }^{3}$, Jawad Hussain ${ }^{4}$ \\ 1,3,4 (PhD Student, Faculty of Management and Human Resource Development, University Technology \\ Malaysia) \\ ${ }_{2}^{2}$ (Associate Professor, Faculty of Management and Human Resource Development, University Technology \\ Malaysia)
}

\begin{abstract}
This review paper critically examines multinational company; discuss its merits and demerits for host countries and debates on its various types of structures and strategies. The main part of this critical review relates about the various types of structures and strategies which multinational companies adopt while conducting business across boarders. It starts by defining Multinational Company discussing its merits and demerits, analysing the various components of its strategies and structures and comparing the merits and demerits of these different types of structures and strategies. A thematic approach rather than chronological approach has been used mainly due to the purpose and approach necessary for such type of review. The thematic approach enables an analysis of a specific topic or theme without considering the chronological order of which the research has been conducted. In latter part this review discusses the relationship of these strategies with international human resource management and also highlights the implications of different companies' strategies and structures for the international human resource management (IHRM). And at end we concluded that the role of IHRM varies in different types of organizational structures and therefore the implications of these structures are also vary for international HRM.
\end{abstract}

Keywords- International Human Resource Management, Models, Structures and Strategies, Multinational Companies

\section{Introduction}

Over the past thirty years, the conceptualization of global strategies by Multinational Corporation has developed dramatically (Adler, 1997: Bartlett, \& Ghoshal 1998), and the implication of these global strategic models for international human resource processes and practices has no less dramatic (Black et al., 1999). Despite these important developments, however, major discontinuities between these global structures and the international human resource processes that are required to implement them remain (Heidenreich, 2012).

The main players in a global knowledge-based economy are multinational companies (MNCs). No one can deny the importance of MNCs in the current global business environment. Multinational Companies coordinate and control subsidiaries across national boundaries and are thus obliged to operate in different national contexts (Heidenreich, 2012).

\section{Objectives Of The Study}

The objectives of this study are:

- to critically examine multinational company; discuss its merits and demerits for host countries and debates on its various types of structures and strategies.

- to critical analyze various types of structures and strategies which multinational companies adopt while conducting business across boarders.

- To study the relationship of these strategies with international human resource management

- To highlights the implications of different companies' strategies and structures for the international human resource management (IHRM).

A thematic approach rather than chronological approach has been used mainly due to the purpose and approach necessary for such type of review. The thematic approach enables an analysis of a specific topic or theme without considering the chronological order of which the research has been conducted. 


\section{Definition Of Mnc}

There is no universally accepted definition of a multinational company available. Multinational Corporations have been broadly defined as business firms that uphold value added-holdings overseas. According to Spero and Hart (1999) a multinational corporation (MNC) as a business enterprise that maintains direct investments overseas and that upholds value-added holdings in more than one country. An enterprise is not truly multinational if it only operates in overseas or as a contractor to foreign firms. A multinational firm sends abroad a package of capital, technology, managerial talent, and marketing skills to carry out production in foreign countries. Dunning (2008) supports the same view and defining MNC as an enterprise that engages in foreign direct investment (FDI) and owns or, in some way, controls value added holdings in more than one country.

Hennart (2008) defines MNC in a different way that they are a privately owned institution devised to organise, through employment contracts, interdependencies between individuals located in more than one country. while Multinational Corporations according to Kogut and Zander (2003) are economic organisations that grow from its national origins to spanning across borders. As an ILO (2010) report observe "The essential nature of a multinational company lies in the fact that its managerial headquarter is located in one country while the company carries out operation in a number of other countries as well."

\section{Merits Of Mncs}

According to Heidenreich, (2012) and ILO (2010) the main merits and demerits of MNCs are:

- Help to increase investment, income and employment in host country.

- Transfer technology to developing countries.

- $\quad$ Make a commendable contribution to inventions and innovations

\section{DEMERITS OF Mncs}

It is true that MNCs have some advantages for host countries however; MNCs have been criticised on the following grounds.

- MNCs technology is designed for world wide profit maximisation, not for the development need of poor countries.

- Through power and flexibility, MNCs can evade national economic autonomy and control, and their activities inimical to the national interest of particular countries.

- MNCS cause fast depletion of some of the non-renewable natural resources in the host country

\section{Strategic Objectives}

In this part of the review we will discuss strategic objectives of MNCs and will show how MNCs follow different competitive strategies to achieve these objectives.

(Bartlett \& Ghoshal, 1992), suggest that, there are three strategic objectives of MNCs.

- Global efficiency

- Flexibility

- Organizational learning (transfer of information)

As Bartlett \& Ghoshal suggest, these objectives are very important for MNCs, although their degree of importance vary from company to company. For global efficiency it is necessary to realize that every possible source of competitive advantage has been identified and utilized. It is important to realize that global efficiency can be enhanced both by increasing revenues and by lowering costs. Important factors influencing efficiency include labour, productivity, capital intensity, economies of scale, learning-curve effects and a company cost culture generally (john et al., 1997)

Multinational flexibility according to Bartlett and Ghoshal (2000) means "the ability of a company to manage the risks and explore the opportunities that arise from the diversity and volatility of the global environment." Lastly, a major objective of MNCs is facilitating learning across units. In addition to encouraging new learning, MNCs also encourage and facilitate the transfer and sharing of new knowledge.

\section{Definition Of Strategy}

According to chandler (1962) "strategy is the determination of the basic long-term goals and objectives of an enterprise and the adoption of courses of action and the allocation of the resources necessary for carrying out these goals"

Bartlett and Ghoshal (2000), distinguish four different strategic approaches that focus on the different combinations of the sources of competitive advantage (the means) and strategic objectives (the ends). 


\section{Multidomestic/ Multinational Strategy}

To achieve different strategic objectives this strategy gives prime importance to one of the means, national differences. This strategy is a collection of relatively independent subsidiaries, each focusing on specific domestic market. The company manages its business with minimal direction from headquarter. By differentiating their products and services to respond to differences in consumer's tastes and preferences and government regulations, these companies achieve global efficiency and increase revenues. Through this responsiveness to national differences they also realize the opportunities associated with multinational flexibility. This is a country-centred strategy therefore, learning remains within country boarders: subsidiaries identify local needs, but also use their own resources to meet these needs. Bartlett \& Ghoshal (2000) call this local-for-local innovation (Harzing \& Ruysseveldt, 2005)

In short, main characteristics of this strategy are below.

- Decentralised and nationally self sufficient.

- Sensing and exploiting local opportunities.

- Knowledge developed and retained within each units.

Example of multidomestic industries includes consumer packaged goods e.g. washing powder and retailing

\section{Advantages}

- Decentralization helps local motivation and morale, therefore, increase the firm's effectiveness.

- Customise product offerings and marketing in according with local responsiveness satisfy customer's taste.

- By responding to local differences these companies also achieve global efficiency and increase revenues.

\section{Disadvantages}

It is true that this strategy has some advantages but some criticism is also levelled against this strategy.

- Inability to realise location economies.

- Failure to exploit experience curve effect.

- Failure to transfer core competencies to foreign markets.

- Lost economies of scale.

\section{International Strategy}

Companies follow an international strategy focus primarily on one of the ends worldwide learning. This kind of strategy is well designed to serve the need for learning through worldwide sharing of innovation. This strategy is effective if a firm faces weak pressures for local responsive and cost reductions, but it does not do a very good job in achieving either global efficiency or flexibility. In this kind of strategy the knowledge and competencies transfer to foreign markets (Marbey \& Salaman, 1995)

Shortly the main characteristics of this strategy are below.

- Sources of core competencies centralized, other's decentralized.

- Weak pressures for local responsiveness and cost reductions.

- Knowledge developed at the centre and transferred to overseas units. Example of this strategy is Mc Donald's.

\section{Advantages}

- Worldwide sharing of innovation.

- This strategy is very efficient at transferring knowledge across boarders.

- Centralization of core competencies.

\section{Disadvantages}

The following is the main criticism levelled against this strategy.

- Lack of local responsiveness.

- Inability to realise location economy.

- Failure to exploit experience curve effect.

- Due to centralized system it harms local motivation and morale, therefore reducing efficiency and flexibility.

\section{Global Strategy}

In this kind of strategy the global corporations use all of their resources in a very integrated fashion. All of their foreign subsidiaries and divisions are highly interdependent in both operations and strategy. This strategy is based on an integration of productions to produce standardized products in a highly cost-efficient way. This strategy is good at achieving the need for efficiency through global integration. The concentration 
and centralization of productions and $\mathrm{R} \& \mathrm{D}$ activities associated with global strategy limit flexibility and leave companies that follow this strategy vulnerable to political and currency risk. They also limit their ability to learn from foreign markets. Therefore, where as in a multi-domestic strategy the managers in each country react to competition without considering what is taking place in other countries, in a global strategy, competitive moves are integrated across nations. The same kind of move is made in different countries at the same time or in a systematic fashion (Albrecht, M.H. (2001)

In short, the following are the main characteristics.

- Centralized and globally scaled.

- Implementation of parent company strategies.

- Knowledge develops and retains in the centre.

- Minimal pressure for local responsiveness.

- Strong pressure for cost reductions.

Example: semi conductor industry, Intel and Motorola.

\section{Advantages}

- By pooling production or other activities for two or more nations, a firm can increase the benefits derives form the economies of scale.

- A firm that is able to switch production among different nations can reduce costs by increasing its bargaining power over suppliers, workers and host governments.

- By locating production in low-cost countries and making standardize product a company can cut costs.

- Worldwide availability, serviceability and recognition can increase performance through reinforcement.

- The company is provided with more points from which to attack and counterattack competition.

\section{Disadvantages}

It is true that this strategy has some advantages but some disadvantages of this strategy are below.

- Through increased, reporting requirements and added staff, substantial management cost can be incurred.

- Over centralization can harm local motivation and morale, therefore reducing the firm's effectiveness.

- Standardization can result in a product that does not totally satisfy any customer.

- Incurring costs and revenues in multiple countries increase risk.

- This strategy also limits the ability to learn from the foreign markets.

\section{Transnational Strategy}

To remain competitive this strategy tries to achieve all strategic objectives at the same time. The transnation strategy provides global coordination (like the global strategy) and at the same time it allows local autonomy (like the multidomestic strategy).It is a kind of combination of global strategy and multidomestic strategy. Transnational strategy offers solution to the competing pressures and involves the creation of an integrated network of units each with a distinct role. It meets all three pressures of local responsiveness, flexibility and global efficiency.

It is based on a combination of location-bound and non-location bound firm-specific advantages.

In short, following are the main characteristics of this strategy.

- High pressure for local responsiveness.

- High pressure for cost reduction.

- Knowledge develops and shares worldwide.

- Transfer of core competences.

Example of this type of strategy is caterpillar.

\section{Advantages}

- Exploitation of experience curve effects and location economies.

- Customise products offering and marketing in accordance with local responsiveness.

- Reap benefits of global learning.

\section{Disadantages}

This strategy is criticised on the following grounds.

- It is a kind of difficult task due to contradictory demands placed on the organization.

- Due to complexity in nature, difficult to implement.

- Lost of economies of scale.

- Units may have power to block initiates and preserve their own autonomy. 


\section{STRUCTURING OF MULTINATIONAL COMPANIES}

Designing an organisation's structure that achieves the multiple strategic objectives of international business is one of the greatest challenges faced by multinational companies in recent decades. The selection of a good competitive strategy is no doubt very important, but a successful implementation of this strategy depends on the structure and processes of the company in question (Harzing \& Ruysseveldt, 2005). In this section we will discuss MNC's structures focussing on the classic approach (classic stages models) of Stopford and Wells and Bartlett and Ghoshal new approach (four models) and also their advantages and disadvantages.

\section{Early Studies}

Chandler (1962) work on the structure of MNCs is considers the early studies on the structure of MNCs. Chandler (1962) distinguished four growth strategies: expansion of volume, geographic dispersion, vertical integration and product diversification. These strategies are called for different structures; hence his adage structure follows strategy. Stopford and Wells's (1972) classic study investigated this relationship in an international context. Stopford and wells (1972) structural stages model was based on empirical investigation of the strategy/structure linkages in 187 large US corporations that define the relationship in terms of two variables (see the figure1.1).

- The number of products sold internally(foreign product diversity, shown vertically in figure1.1) and

- The proportional importance of foreign sales to total sales (percentage foreign sales, shown horizontally)

A model was constructed that show how MNCs adopt different organisational structures at different stages of international expansion (see figure 1.1)

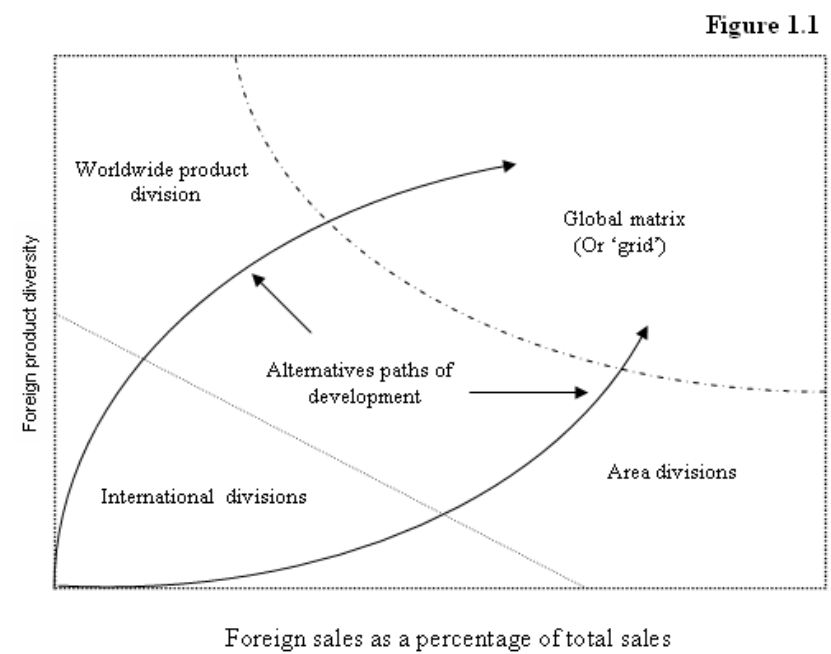

Stopford and Well's international structural stages model (adapted from Stopford and wells, 1972)

\section{International Division Structure}

This type of structure is to be used when both product diversity and foreign sales are low. All the international activities are simply concentrated in one international division and the domestic organizational structure is left untouched. It is a simple and understandable structure and it does not need a complete overhaul of the organization.

\section{ADVANTAGES}

- It creates a central pool of international; experience and expertise.

- It is effective in cost reduction.

\section{Disadvantages}

- Isolation of domestic and international activities limits the transfer of knowledge.

- Lack of coordination.

- Division between domestic and international activities hinder the company's effectiveness and efficiency.

\section{Area Division Structure}

This structure prioritizes the geographic or territorial dimension and the MNCs primary division which are based on area. This structure is good for a company with narrow product line (low level of foreign product 
diversity). In this case the world is divided into separate areas, depending on the size of the market. Each area operates rather in an autonomous way.

\section{Advantages}

- Responsive to local differences and taste.

- This structure works well if a company has a narrow product line.

\section{Disadvantages}

- Lack of coordination.

- Failure to transfer information and experience.

\section{Product Division Structure}

This structure is to be particularly suitable for diversified MNCs with wide products range. In this kind of structure the divisions are created for each product or group of products, and these division are relatively independent and autonomous and are responsible for their own value-creating activities (production, $R \& D$, marketing etc)

\section{Advantages}

- Due to coordination \& rationalization within product group, efficiency is improved.

- High degree of integration and economies of scale.

- Transfer of core competence and knowledge.

\section{Disadvantages}

- Less responsive to local conditions and differences.

- Corporate level strategy may be weak in this structure.

\section{Global Matrix Structure}

When a company enters into a stage, where both foreign sales and product diversity are high, then global matrix is the ideal structure. This structure combines the advantages of both of the area and product structure, local responsiveness and global efficiency. In this structure the responsibility for a particular product is shared by both product and area managers (Harzing \& Ruysseveldt, 2005).

\section{Advantages}

- This structure helps a company to balance product and area requirements and achieve both efficiency and responsiveness.

- Transfer of learning and knowledge

\section{Disadvantages}

- Decision making processes become slow and bureaucracy increased.

- Lack of responsibility and flexibility.

\section{Recent Development}

Nowadays some recent and sophisticated approaches have been developed. Here we will discuss these recent develop structures described by Bartlett and Ghoshal (2000), multinational, international, global, and transnational.

\section{Multinational Organizational Model}

This was the classic organization pattern adopted by companies in pre-war period. Economic, political and social forces encouraged multinational companies to decentralize their organisational assets and capabilities to allow foreign operations to respond differences that distinguish national markets. So the foreign operations were relatively independent of the headquarters. Control and coordination were achieved primarily through the personal relationship between top corporate management and subsidiary managers. Products were customised to meet differing local demands. This structure gives prime importance to local responsiveness. Decentralized federation is the main characteristic of this structure. Example of a multidomestic industry is the branded packaged products industry e.g. food and laundry detergents.

\section{Adavantages}

The main advantage of this structure is that it gives prime importance to local responsiveness, and through this achieves global efficiency. 


\section{Disadvantages}

The main disadvantages of this structure are the inability to realize location economies and also failure to exploit experience curve effect.

\section{International Organizational Model}

This type of organizational structure developed in the early post-war decades. The main objective for the companies in those days was to transfer knowledge and expertise to overseas environments that were less advanced in technology or market development. Local do still have some freedom to adopt new products or strategies, but more important than in the multidomestic type. Some functions in the international model are centralized and others are decentralized, in particular knowledge, research and development take place at the centre and are subsequently transferred to subsidiaries. A classic example of an international industry is telecommunications switching.

\section{Adavateges}

The main advantages of this structure are sharing of worldwide innovation and transfer of knowledge from centre to subsidiaries.

\section{Disadvantages}

The main disadvantages are the lack of local responsiveness and inability to realise location economy.

\section{Global Organizational Model}

This type of structure emphasises on efficiency, centralization and control. In global industry, standardize consumer needs and scale efficiencies make centralization and integration profitable. In this kind of industry a firm competitive position is significantly influenced by its position in other countries and rivals compete against each other on truly worldwide basis. In this type of structure the role of offshore subsidiaries is limited, only to assemble and sell products and implement plans and policies developed at headquarters. As compared with multidomestic and international organizational mode the subsidiaries in this organizational model have much less freedom of action. The structural configuration of this organization is called central hub. The example of a global industry is consumer electronics (Jain, 1989)

\section{Adavantages}

By locating production in low cost countries and making standardize product a company keeps costs low.

\section{Disadvantage}

This structure limits the ability to learn from the foreign markets and over centralization harms the motivation and therefore, reducing the firm's effectiveness.

\section{Transnational Organization Model}

To remain competitive this model achieves all three strengths (efficiency, flexibility and local responsiveness) simultaneously. In 1980s many worldwide industries have adopted transnational form. This type of structure is a complex configuration of assets and capabilities in which some functions and resources are centralized and others decentralized, creating an independent network of specialized units. Expertise is spread throughout the organization and subsidiaries can serve as a strategic centre for particular product-market combination. This concept is against the traditional concept of having one headquarter and many dependant subsidiaries. In this type of structure the company becomes a kind of network with different centres for different activities. Each centre has a strategic role for a particular area. Example of this kind of structure is caterpillar.

\section{Advantages}

The main advantage of this structure is exploitation of experience curve effect and location economies. 


\section{Disadvantage}

Due to its complex nature this structure is difficult to implement.

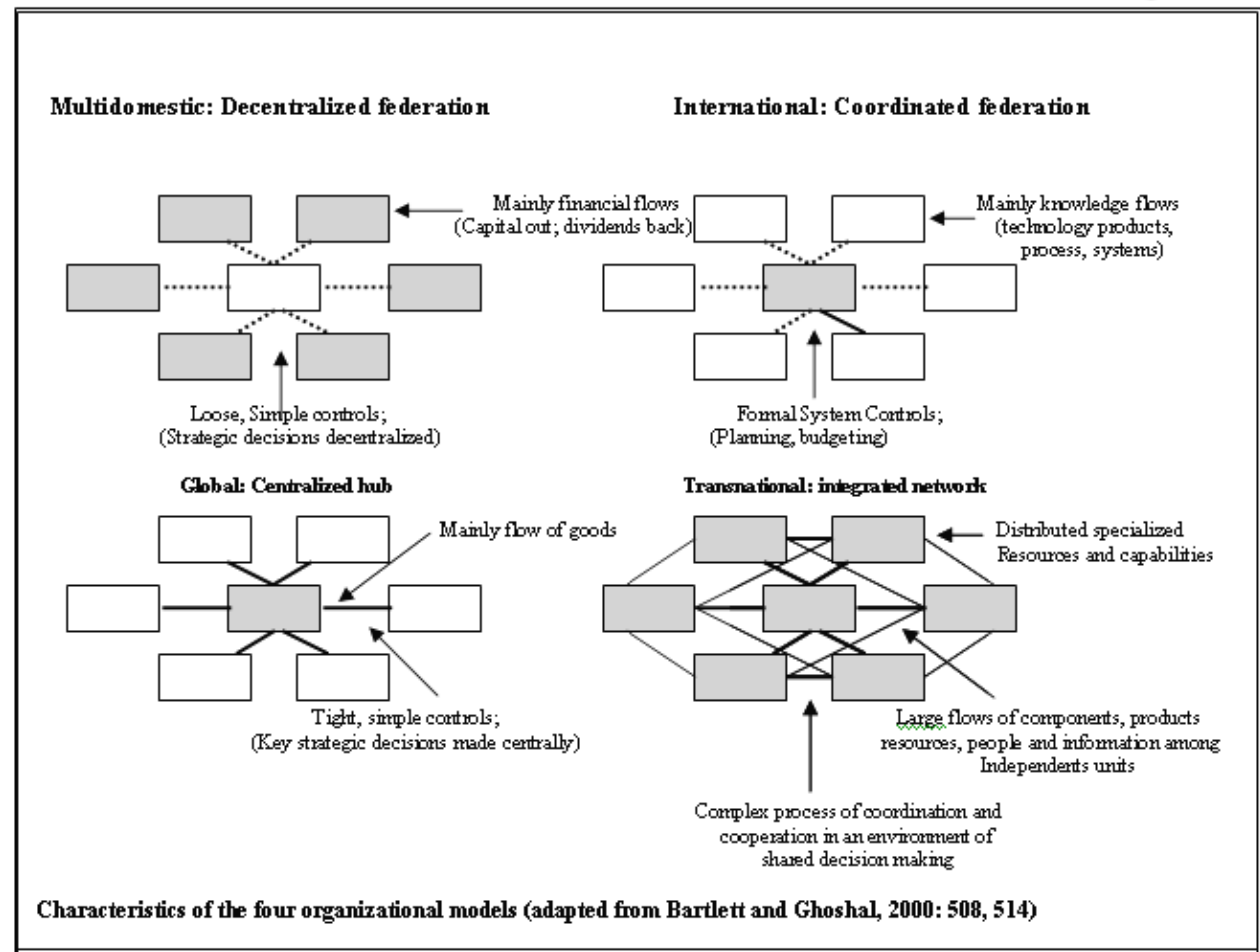

XII. Implications Of Different Company Strat-Egies And Structures For International Hrm

To operate in an international environment a human resource department must engage in a number of activities like, human resource planning, staffing, training and development, compensation, performance management and industrial relations. In this portion of literature review we will discuss the role of IHRM or implications for IHRM in context of different types of strategies and structures.

\section{Human Resource Plaining}

We use the concept of HR policy in generic sense for a wide range of policies, procedures and processes, which aim at managing, discipline, motivating and rewarding employees in work organization. IHRM here link the understanding of HR policy to a wide range of company values \& strategies, i.e. HR is more or less integrated in the company culture. It suggests that HR policy not only is a question about education and training of employees, but also aim at managing the relation between employer and employees and development of reflexive workforce (Kettunen, 1998). Moreover, it suggests, that success of HR policy is closely connected to organization and competence development.

The challenge is to establish an agenda that motivates employees to become involved and committed to company strategies. The main task of IHRM is making and implementation of HR programme which enable a firm to be successful globally.

\section{STAFFING (Recruitment, Selection And Placement)}

The difference between failure and success depends how well organizations select, train and manage their employees. For international staffing Perlmutter's (1969) classic study has described three different approaches, ethnocentric, polycentric and geocentric. Companies follow ethnocentric staffing approach would mostly appoint parent company nationals. In this type of approach the nationals from parent company dominate the organisation at home and abroad. While companies follow the polycentric approach appoint mostly nationals from host countries, and companies follow geocentric approach appoint the best persons regardless of their nationality.

Now linking these different types of staffing approaches to Bartlett and Ghoshal (2000) organizational models as discussed earlier. Global and (up to some extent) international organisational models follow ethnocentric approach, multidomestic polycentric and transnational geocentric approach.

International HRM is concerned with ethnocentric staffing policy because in ethnocentric policy the recruitment and selection are made at headquarters and subsidiaries have limited autonomy. So, in global and international models the selection of expatriates, their training, preparation and placement for international role and the 
control of human resource in diverse and dispersed population of host countries is the main and crucial role of IHRM. In this processes the IHRM faces a lot of implications like cultural differences, communication problem, relocation and remuneration.

\section{Training And Development}

Multinational companies recognize that human resources play an important role in developing and sustaining a competitive advantage in today's highly competitive global business environment (Brewster, 2000). The training and development of the human resources perform a variety of purposes such as to acquire and transfer knowledge, to manage foreign subsidiary and to maintain communication coordination and control between subsidiaries and headquarters. In global and a bit in international organisational models training originates at headquarters and corporate trainers travel to subsidiaries. To remain globally competitive the IHRM must identify employees with global potential and provide them various training and development opportunities. While in multidomestic and transnational organizational models the training and developments activities carry out on local basis.

\section{Compensation \& Reward}

After selection, training and development of employees, another implication for IHRM is how to compensate employees in multinational companies. International compensation can be defined as the provision of monetary and non monetary rewards, including base salary, benefits, long and short-term incentives, valued by employees in accordance with their relative contributions to MNC performance. Its broad HRM purpose is to attract, retain and motivate those personnel throughout the MNC currently and in the future (Harzing \& Ruysseveldt, 2005). In multinational companies the IHRM is mainly concerned with the compensation and reward of employees in global and international structure models, because in global and international models the compensation and reward system is develop and administer in headquarters. While in multidomestic and transnational structures compensation and reward system is develop in different units and regulated by local HRM. Compensation and reward system for international expatriate is much more complex. The IHRM looks into various things like foreign services premium, hardship, relocation, education and home leave etc, when giving compensation to international expatriate.

\section{Performance Management}

Performance management in different types of strategies and structures is another implication for IHRM. Performance management means systematic appraisal of employee's performance within an organization.

In multidomestic and transnational organizational models this is the duty of local HRM, while in global and (to some extent) in international models for performance management the IHRM uses different practice base on different theories like expectancy theory and goal setting theory. In MNC the performance management is more complex as it occurs across national and cultural boundaries.

\section{Industrial Relation}

Industrial Relation identifies and defines the roles of management and workers in workplace. Managing industrial relation is another task for IHRM. In global and a little bit in international models the IHRM manage the industrial relation taking into account the governmental regulations and role of trade unions in different countries.

In addition to these, international taxation, international relocations and language problem etc are also some others important implications for IHRM.

\section{Conclusion}

Bartlett \& Ghoshal (2000) prescribed four different strategic approaches that focus on the different combinations of the sources of competitive advantage (the means) and strategic objectives (the ends).

To compete effectively, achieve global advantages and remain globally competitive Multinational Companies follow different strategies and structures. In this literature review we have defined MNC, critically analysed its different strategies and structures and compared strengths and weaknesses of these strategies and structures with each others.

In latter part of this review we have mentioned that that international HRM has crossed the early stage of development and through strategic IHRM a multinational company can achieve competitive advantage. In this literature review we have also discussed that the role of IHRM varies in different types of organizational structures and therefore the implications of these structures are also vary for international HRM.

In last section of this review we have prescribed some general implications of a company's different strategies and structures for IHRM and have discussed how IHRM faces these implications and manages the human resources worldwide. 


\section{References}

[1] Adler, N.J. (1997) International Dimension of organisational behaviour, $3^{\text {rd }}$ edition. Cincinnati, south west college publishing.

[2] Bartlett, C., and S. Ghoshal (1998) Managing across Borders: The Transnational Solution, $2^{\text {nd }}$ edition. London: Random House.

[3] Black, J.S., H.B. Gregerson, M.E. Mendenhall and L.K.Stroh, (1999) Globalizing people through International Assignments. Reading, MA: Addison-Wesley.

[4] Heidenreich, M. (2012) The social embeddedness of multinational companies: a literature review, Socio-Economic Review, pp. 549-579

[5] Spero, J., Hart, J. (2003) The Politics of International Economic Relations, London, Thompson Wadsworth.

[6] Dunning, J.H. (2008) Multinational Enterprises and the Global Economy, UK, Edward Elgar Publishing Limited.

[7] Hennart, J.F. (2008) The Future of Multinational Enterprise,", Netherland, Academy of Management Annual Meetings.

[8] Kogut, B. Zander, U. (2003) A Memoir and Reflection: Knowledge and an Evolutionary Theory of the Multinational Firm 10 years later, Journal of International Business Studies, pp.505-515

[9] International labour organisation (2010) International institute for labour studies, (www).Available from: http//www.ilo.org/inst (accessed 06 Jan 2012)

[10] Bartlett, C., and Ghoshal, S. (1992) Transnational management. Homewood, IL: Irwin.

[11] John, R., Gillies, G.L., Cox, H., Grimwade, N. (1997) Global Business Strategy, London, International Thomson Business Press.

[12] Bartlett, C.A., Ghoshal, S. (2000) Transnational Management: Text, Cases and Readings in Cross-Border Management, $3^{\text {rd }}$ edition, Boston: Irwin McGraw Hill.

[13] Chandler, A.D. (1962) Strategy and Structure: Chapters in the History of Industrial Enterprise, Cambridge, MA: MIT Press

[14] Harzing, A.W., Ruysseveldt, J.V. (2005) International Human Resource Management, London, SAGE Publication Ltd.

[15] Mabey, C., Salaman, G. (1995) Strategic Human Resource Management, Oxford, Blackwell Publishers Ltd.

[16] Albrecht, M.H. (2001) International HRM: Managing Diversity in the Workplace, UK, TJ International Ltd.

[17] Stopford, J.M., Wells, L.T. (1972) Managing the Multinational Enterprise: Organization of the firm and ownership of the subsidiaries, New York, Basic Books.

[18] Jain, S.C. (1989) Standardization of International Marketing Strategy: Some Hypotheses, Journal of Marketing, January 1989. vol.53, pp.70-79.

[19] Perlmutter, H.V. (1969) The Tortuous Evolution of the Multinational Company, Columbia Journal of world business ,pp.9-18.

[20] Brewster, C. (2000) 'European human resource management', in M.Warner (ed.), International Encyclopaedia of Business and Management: Management in Europe. London: Thomson. 